\title{
POSISI HUKUM AGAMA (HUKUM ISLAM) DALAM RANAH POLITIK INDONESIA
}

\author{
Oleh: \\ Andrie Irawan \\ Universitas Cokroaminoto Yogyakarta
}

\begin{abstract}
Abstak
Tulisan ini mengangkat hukum Islam dalam politik ketatanegaraan Indonesia karena memang pada umumnya banyak pengaruh peraturan perundang-undangan yang dipengaruhi oleh hukum Islam seperti dijabarkan dalam tulisan ini. Peran hukum agama (hukum Islam) dalam ranah politik Indonesia diwujudkan dalam bentuk peraturan perundang-undangan yang memuat materi-materi hukum Islam tanpa harus memunculkan ketentuan-ketentuan Islam secara harfiah selain itu memang di dalam falsafah hidup bangsa Indonesia (Pancasila) dan konstitusi negara Indonesia (Undang-Undang Dasar Negara Republik Indonesia tahun 1945) dinyatakan bahwa kedudukan hukum agama merupakan hal penting dalam menjaga dan mengawal kehidupan bangsa yang tidak hanya hukum Islam semata tetapi juga hukum-hukum agama lain yang ada di Indonesia.

Keberadaan hukum Islam dan hukum agama lainnya merupakan penopang dari pembagunan nasional selama pihak-pihak yang terkait dapat mengoptimalkan antara kelebihan dan kekurangan yang dimiliki hukum-hukum agama di Indonesia. Sehingga dapat ditarik kesimpulan bahwa konsep sekulerisme dalam politik Indonesia dapat diminimalisir serta dengan penggunaan materi-materi hukum agama dalam ranah politik Indonesia akan menjadikan khasanah yang baik dan lebih terarah.
\end{abstract}

Kata Kunci: Hukum Agama (Islam), Politik, Indonesia

\section{A. Pendahuluan}

Sejak abad ke-19, tumbuh kontak yang semakin intensif antara dunia Islam dengan peradapan barat. Kontak tersebut melahirkan dampak yang mencengangkan bagi perubahan struktur peradaban dunia Islam. Fauzul Rahman menyebutnya sejarah Islam modern, khususnya mulainya abad tersebut, pada hakikatnya merupakan sejarah dampak barat atas masyarakat muslim. Sejak saat itu pula perkembangan hukum didunia Islam ${ }^{1}$ yaris ditentukan dan didikte

\footnotetext{
1. Muhammad Daud Ali, Hukum Islam Pengantar Ilmu Hukum Dan Tata Hukum Islam Di Indonesia, Jakarta. Raja grafindo persada, 1993, hal. 240-241.
} 
oleh pengaruh-pengaruh barat. Hukum Islam yang semula menepati posisi sentral dalam sistem hukum mereka dengan serta merta tersisihkan dan tercampakkan pada posisi marginal.

Setelah dunia Islam mendapatkan kembali kemerdekaannya secara pilitik dari cengkraman imprealisme barat pada abad ke-20 ini, tampak upaya-upaya menarik dan mengangkat kembali hukum Islam kemudian mendefenisikannya dalam skema hukum nasional mereka. Hukum nasional yang dimaksut adalah hukum yang berlaku bagi bangsa tertentu di suatu Negara tertentu. Untuk konteks Indonesia, hukum nasional berarti hukum yang dibangun oleh Negara Indonesia sebagai pengganti hukum kolonial. Ia merupakan kumpulan norma-norma yang hidup dan berkembang dalam masyarakat yang bersal dari unsur-unsur hukum Islam, hukum Adat, hukum Barat. ${ }^{2}$ Dalam sistem hukum nasional Indonesia ketiga unsur tersebut memiliki posisi tawar (bargaining position) yang berbeda-beda. Hingga kini bahkan dimasa-masa yang akan datang para pendukung dari masing-masing unsur hukum tersebut berupaya untuk menaikkan posisi tawar masing-masing dalam rangka turut melandasi dan memberikan warna bagi bangunan hukum nasional yang hendak diwujudkan.

Badan Pembinaan Hukum Nasional Kementerian Hukum dan Hak Asasi Manusia merencanakan suatu proyek penelitian mengenai eksistensi hukum Islam yang sejak dulu dipahami sebagai bagian yang tidak terpisahkan dari kesadaran masyarakat Indonesia mengenai hukum dan keadilan yang memang jelas keberadaan atau eksistensinya dalam kerangka sistem hukum nasional. Secara instrumental banyak ketentuan perundang-undangan Indonesia yang telah mengadopsi berbagai materi hukum Islam ke dalam pengertian hukum nasional. Hal tersebut tentunya ketika banyak peraturan perundang-undangan yang mengadopsi beberapa materi dalam hukum Islam tentunya juga akan berpengaruh dalam perpoltikan di lembaga parlemen dalam memuluskan jalannya beberapa peraturan perundang-undangan yang telah mengadopsi materi-materi Islam. Secara sosiologi empirik praktek-praktek penerapan hukum Islam ditengah-tengah masyarakat juga terus berkembang dan bahkan semakin lama makin meningkat dan meluas kesektor-sektor kehidupan hukum yang sebelumya belum ditetapkan menurut ketentuan hukum Islam. Bahkan berpengaruh pula pada pendidikan hukum ditanah air,

2. Amrullah Ahmad SF. (ed) Bustanul Arifin, Pikiran Dan Peranannya Dalam Pembangunan Hukum Islam Di Indonesia, Jakarta, Geme Insani Press, 1996, hal. 40 
sehingga kepakaran dan penyebaran kesadaran mengenai eksistensi hukum Islam di Indonesia makin meningkat pula dari waktu kewaktu.

\section{B. Sejarah Hukum Islam di Indonesia}

Berdasarkan formulasi yang sederhana dapat dinyatakan bahwa pada hakitnya hukum Islam di Indonesia adalah norma-norma hukum yang bersumber dari syari'ah (Al Qur'an dan Hadist) yang pemahammanya tumbuh dan berkembang dalam kehidupan masyarakat sepanjang bentangan sejarah Indonesia. Hukum terlahir berupa perkawinan hukum Islam yang normatif (syariah) dengan muatan-muatan lokal Indonesia. Untuk meilhat hukum Islam di Indonesia secara utuh, penggunaan perspektif historis sangat penting menjadi sebuah dasarnya.

Seluruh umat Islam sepakat bahwa sebagai agama Islam mengatur seluruh aspek kehidupan sosial dengan seperangkat norma, termasuk norma hukum. Al-Qur'an banyak memuat ketentuan-ketentuan umum. Kemudian sejak awalnya Nabi Muhammad SAW telah membentuk struktur hukum dalam mengatur kehidupan masyarakat dalam bentuk hadist, dan demikian penerimaan Islam sebagai agama, including di dalamnya penerimaan terhadap hukum Islam.

Berdasarkan teori ini, maka dapat dinyatakan bahwa keberadaan hukum Islam di Indonesia adalah bersamaan dengan keberadaan Islam di Indonesia. Ketika masyarakat Indonesia menyatakan Islam (menjadi umat Islam), secara otomatis berarti mengakui otoritas hukum Islam atas dirinya baik pribadi maupun secara komunal.

Keberadaan lembaga-lembaga pengadilan seperti lembaga "tahkim" dan "tauliyah" semakin memperkokoh teori ini. ${ }^{3}$ Selain itu sistem hukum yang berlaku di kerajaan-kerajaan Islam nusantara juga menunjukkan bahwa hukum Islam menepati posisi penting dalam penyelesaian perkara-perkara hukum.

Dengan munculnya teori receptie ini, posisi hukum Islam menjadi termarjinalkan hingga masa kemerdekaan. Pada masa ini setelah disyahkannya Undang-Undang Dasar 1945, mulailah upaya-upaya pemberlakuan hukum Islam secara lebih proporsional.

Hazairin tahun 1950 memberikan pndangan agar hukum Islam diberlakukan, tidak atas dasar hukum adat, pada tahun 1963 Hazairin menegaskan lagi bahkan ia menyatakan teori receptie teori iblis yang jelas-jelas bertentangan dengan Al-Quraan dan Sunnah. Pada tahun 1969

\footnotetext{
3. Syazali Mustofa, Pengantar Dan Azaz Hukum Islam Di Indonesia, Solo, Rahmadhani, 1990, hal. 59-60
} 
Hazairin kembali menegaskan tidak berlakunya teor receptie karena telah dihapuskan secara meyakinkan oleh pembukaan dan pasal 29 Undang-Undang Dasar 1945, Hazairin mempopulerkan teorti receptie a contrario kebalikan dari teori receptie yang mana bukan lagi hukum Islam yang mengikuti hukum adat, tetapi justru hukum adat baru bisa berlaku jika tidak bertentangan dengan hukum Islam. ${ }^{4}$

Berdasarkan teori ini, maka dapat dinyatakan bahwa keberadaan hukum Islam di Indonesia adalah bersamaan dengan keberadaan Islam di Indonesia. Oleh karena itu ketika masyarakat Indonesia menyatakan Islam, secara otomatis mengakui hukum Islam atas dirinya inilah yang disebut teori syahadat.

Keberadaan lembaga-lembaga perdilan seperti lembaga tahkim dan tauliyah dari Ahl AlHalli Wa Aqdi semakin mengokohkan teori ini. Disamping itu sistem hukum yang berlaku pada kerajaan-kerajaan Islam nusantara, seperti pasai kerajaan mataram, kerajaan banjar dan lainnya, juga meenunjukkan bahwa hukum Islam menepati posisi penting dalam menyelasaikan perkara hukum.

Adapun upaya politik untuk menyertakan hukum agama dalam perundang-undangan negara kita dengan merubagah teori receptie dengan teori yang digulirkan oleh Hazairin dan kawan-kawan dengan teori receptie a contrario, kita dapat memlihat dengan lahirnya undangundang No 1 Tahun 1974 tentang perkawinan, ini merupakan pukulan telak bagi teori receptie dan lahirnya undang-undang No 7 Tahun 1989, maka teori receptie tidak lagi mendapatkan tempat dalam hukum di Indonesia dan keberadaan hukum Agama semakin mendapatkan tempat dan kokoh dalam kehidupan hukum di Indonesia.

Berdasarka tinjauan historis tersebut, maka dapat ditegaskan bahwa sepanjang sejarah perjalanan hukum di Indonesia, kehadiran hukum Islam dalam hukum nasional merupakan perjuangan eksistensi. Dalam bentangan sejarah itu pula, hukum Islam memperteguh eksistensinya baik sebagai hukum tertulis maupun hukum tidak tertulis, dalam berbagai lapangan kehidupan hukum dan praktek hukum. Ini merupakan teori eksistensi. Keberadan hukum Islam dalam hukum nasional dapat dibedakan dalam empat bentuk; 1) "ada" dalam arti sebagai bagian integral dari hukum nasional Indonesia, 2) "ada" dalam arti diakui kemandiriannya, kekeuatan dan kewibawaannya oleh hukum nasional, 3) "ada" dalam fungsinya penyaring (filter) bagi

\footnotetext{
${ }^{4}$. Hazairin ed Suyuti Thalib, Pembaharuan Hukum Islam In Memoriam, UI Press, Jakarta, 1981, hal. 52-53
} 
materi hukum nasional Indonesia, dan 4) "ada" dalam arti sebagai bahan utama dan unsur utama bagi pembentukan hukum nasinal. ${ }^{5}$

Dengan demikian tampak bahwa hukum Islam merupakan bagian yang tak terpisahkan dari hukum nasional. Hukum Islam merupakan sub sistem dari sistem hukum nasional, sebagai sub sistem hukum nasional, hukum Islam diharapkan dapat memberikan kontribusi yang dominan dalam rangka pengembangan dan pembaharuan hukum nasional yang mencerminkan kesadaran hukum masyarakat Indonesia.

\section{Hukum Islam Dalam Era Otonomi Daerah}

Dalam rangka kebijakan otonomi daerah dapat dipersoalkan mengenai sejauh mana hukum dan sistem hukum dapat didesentralisasikan, berdasarkan konsep kekuasaan yang diatur dalam Undang-Undang Nomor 23 Tahun 2014 tentang Pemerintahan Daerah jo Undang-Undang Nomor 9 Tahun 2015 tentang Perubahan Kedua atas Undang-Undang Nomor 23 Tahun 2014 tentang Pemerintahan Daerah, kekuasaan peradilan termasuk urusan yang tujukan sebagai kewenangan pemerintahan pusat. Jika kekuasaan perdilan dipahami dalam pengertian institusi peradilan yang terstruktur mulai dari pengadilan tingkat pertama sampai ingkat Mahkamah Agung, maka pembinaan administrasinya dan pengelolaan sistem peradilannya tentu tidak dapat disentrelisasikan, karena kekuasaan peradilan sesuai dengan ketentuan Undang-Undang Dasar Negara Republik Indonesia tahun 1945 berpuncak pada Mahkamah Agung yang mandiri dan menurut Undang-undang Nomor 3 Tahun 2009, baik urusan acara peradilan maupun administrasi peradilan dikembangkan dengan satu atap di bawah Mahkamah Agung.

Dalam pasal 18 ayat 5 perubahan Undang-Undang Dasar Negara Republik Indonesia Tahun 1945 dinyatakan "pemerintah daerah menjalankan otonomi daerah seluas-luasnya, kecuali urusan pemerintahan yang oleh undang-undang ditentukan sebagai urusan pemerintahan pusat. Dalam ayat 6 pasal 18 dinyatakan pula pemerintahan daerah berhak menetapkan peraturan daerah dan peraturan lain untuk melaksanakan otonomi dan tugas pembantuan. Bahkan dalam pasal 18B ayat 1 dijelaskan "Negara mengakui dan menghormati satuan-satuan pemerintah dearah yang bersifat khusus atau bersifat istimewa yang diatur dengan undang-undang" dalam ayat 2 dinyatakan "negara mengakui dan menghormati kesatuan-kesatuan masyarakat hukum

\footnotetext{
${ }^{5}$ Abdul Halim Barskatullah dan Teguh Prasetyo, Hukum Islam, Pustaka Pelajar, Yogyakarta, 2006, hal. 71
} 
adat beserta hak-hak tradisionalnya sepanjang masih hidup dan sesuai dengan perkembangan masyarakat dan prinsip Negara Kesatuan Republik Indonesia yang diatur dalam undangundang".

Artinya Undang-Undang Dasar Negara Republik Indonesia Tahun 1945 mengakui dan menghormati pluralisme hukum dalam masyarakat, meskipun sistem peradilan nasional bersifat terstruktur dalam kerangka sistem nasional, materi hukum yang menjadi pegangan oleh para hakim dapat dikembangkan secara beragam. Bahkan secara historis, sistem hukum nasional Indonesia seperti dikenal sejak lama memang bersumber dari sub sistem hukum, yaitu sistem barat, sistem hukum adat, dan sistem hukum Islam dan ditambah dengan praktek-praktek yang dipengaruhi oleh berbagai perkembangan hukum nasional sejak kemerdekaan dan perkembangan-perkembangan yang diakibatkan oleh pengaruh pergaulan bangsa Indonesia dengan tradisi hukum dari dunia internasional.

Oleh karena itu sumber-sumber tradisi hukum adat masyarakat kita yang hidup, sumbersumber tradisi hukum yang dihayati secara mendalam dalam keyakinan keagamaan masyarakat kita, dan bahkan suber norma hukum yang sama sekali asing sekalipun, sepanjang itu memang kita butuhkan untuk mewujudkan keadilan dan kebenaran serta kedamaian hidup, tidak mungkin kita tolak pemberlakuannya dalam kesadaran hukum masyarakat dan bangsa kita.

Di Indonesia, khususnya dalam bidang hukum, terdapat rasa optimisme di kalangan pakar hukum bahwa di masa-masa yang akan datang, hukum Islam akan mendominasi hukum nasional. Baharudin Lopa menyatakan bahwa peradilan di Indonesia di masa depan akan lebih banyak berdasarkan ajaran-ajaran Islam. ${ }^{6}$

Pernyataan ini perlu segera dikritisi lebih jauh, yakni dengan melihat secara objektif keberadaan hukum Islamn dewasa ini, dimana letak kekuatannya dan kelemahannya, sejauh mana peluang dan hambatannya, baru setelah itu kita lihat prospek hukum Islam secara lebih akurat dalam politik hukum Indonesia.

Ada beberapa hal yang menjadi kekuatan hukum Islam sebagai berikut:

a. Karakter hukum Islam yang universal dan fleksibel serta memiliki dinamika yang sangat tinggi, karena ia memiliki dua dimensi, thubut (konsistensi) dan tatawwur (transformasi)

\footnotetext{
${ }^{6}$ Nurcholish Madjid, Islam Di Indonesia Dan Potensinya Sebagai Sumber Ideology Dan Etos Nasional, ed. Budhi Munawarman Rahmad, Kontekstualisasi Doktrin Islam Dalam Sejarah, Jakarta, 1995, hal. 579
} 
yang memungkinkan hukum Islam selalu relevan dengan perubahan spesial dan temporal yang selalu terjadi.

b. Sebagai hukum yang bersumber pada agama, hukum Islam memiliki daya ikat yang kuat, tidak terbatas sebagai aturan yang berdimensi profanhumanistik, akan tetapi juga berdimensi transedental.

c. Hukum Islam didukung mayoritas penduduk Indonesia, karena mayoritas penduduk Indinesia beragama Islam.

d. Secara historis dan sosiologis hukum Islam telah mengaka dalam peraktek kehidupan masyarakat.

Adapun peluang hukum Islam dalam politik hukum Indonesia sebagai berikut:

a. Pancasila sebagai sumber dari segala sumber hukum di Indonesia dan UUD 45 sebagai konstitusi negara memberi kedudukan penting bagi agama. Hal ini membuka peluang bagi dikembangkannya hukum yang bersumber dari agama.

b. Pengembangan hukum, sebagaimana digariskan dalam GBHN diarahkan untuk tumbuhnya kesadaran masyarakat. Kesadaran hukum masyarakat yang mayoritas beragama Islam tidak bisa dilepaskan dari hukum Islam. Ini berarti hukum nasional yang dikehendaki Negara Republik Indonesia adalah hukum yang menampung dan memasukkan hukum agama dan tidak memuat norma yang bertentangan dengan hukum agama.

c. Adanya politik will dari pemerintah bagi berkembangnya hukum Islam dalam sistem hukum nasional meskipun masih terbatas

d. Berdasarkan penelitian, masyarakat Indonesia memiliki keinginan kuat berhukum dengan hukum agama (hukum Islam). Tampaknya ini parelel dengan ramalan futurolog John Naisbit yang menyatakan bahwa kecenderungan umat manusia di masa depan akan kembali kepada agama.

Berdasarkan pemetaan terhadap kondisi objektif hukum Islam tersebut, maka dapat ditegaskan bahwa prospek hukum Islam dalam sistem hukum nasional akan sangat mengembirakan, sepanjang pihak-pihak yang terkait dalam pembangunan hukum Islam mampu 
untuk mengoptimalkan kekuatan dan peluang yang dimiliki hukum Islam serta mampu untuk mengeliminir kekurangan dan hambatan yang ada dan mencarikan solusinya.

\section{Penutup}

Sebelum menjawab pertanyaan pada soal kedua ini, alasan dari tulisan ini mengangkat hukum Islam dalam politik ketatanegaraan Indonesia karena memang pada umumnya banyak pengaruh peraturan perundang-undangan yang dipengaruhi oleh hukum Islam seperti dijabarkan dalam tulisan ini. Kembali kepertanyaan awal, bahwa peran hukum agama (hukum Islam) dalam ranah politik Indonesia diwujudkan dalam bentuk peraturan perundang-undangan yang memuat materi-materi hukum Islam tanpa harus memunculkan ketentuan-ketentuan Islam secara harfiah selain itu memang di dalam falsafah hidup bangsa Indonesia (Pancasila) dan konstitusi negara Indonesia (Undang-Undang Dasar Negara Republik Indonesia tahun 1945) dinyatakan bahwa kedudukan hukum agama merupakan hal penting dalam menjaga dan mengawal kehidupan bangsa yang tidak hanya hukum Islam semata tetapi juga hukum-hukum agama lain yang ada di Indonesia.

Selain itu patut juga menjadi perhatian bahwa keberadaan hukum Islam dan hukum agama lainnya merupakan penopang dari pembagunan nasional selama pihak-pihak yang terkait dapat mengoptimalkan antara kelebihan dan kekurangan yang dimiliki hukum-hukum agama di Indonesia. Sehingga dapat ditarik kesimpulan bahwa konsep sekulerisme dalam politik Indonesia dapat diminimalisir serta dengan penggunaan materi-materi hukum agama dalam ranah politik Indonesia akan menjadikan khasanah yang baik dan lebih terarah. 


\section{Daftar Pustaka}

Abdul Halim Barskatullah dan Teguh Prasetyo, Hukum Islam, Pustaka Pelajar, Yogyakarta, 2006

Amrullah Ahmad SF. (ed) Bustanul Arifin, Pikiran Dan Peranannya Dalam Pembangunan Hukum Islam Di Indonesia, Jakarta, Geme Insani Press, 1996

Hazairin ed Suyuti Thalib, Pembaharuan Hukum Islam In Memoriam, UI Press, Jakarta, 1981

Muhammad Daud Ali, Hukum Islam Pengantar Ilmu Hukum Dan Tata Hukum Islam Di Indonesia, Jakarta. Raja grafindo persada, 1993

Nurcholish Madjid, Islam Di Indonesia Dan Potensinya Sebagai Sumber Ideology Dan Etos Nasional, (ed). Budhi Munawarman Rahmad, Kontekstualisasi Doktrin Islam Dalam Sejarah, Jakarta, 1995

Syazali Mustofa, Pengantar Dan Azaz Hukum Islam Di Indonesia, Solo, Rahmadhani, 1990 